\title{
A Study of Dermatoglyphics in Insulin Dependent Diabetes Mellitus
}

\author{
Dr.K.Sumangala Devi*, Dr.Mohammed Meraj Ahmed*
}

\section{Introduction}

The Skin on the Palmar and Plantar Surfaces is grooved by curious ridges, which form a variety of configurations. Each individual's ridge configurations are unique. The dermal ridge differentiations are genetically determined and influenced by environmental factors. It provides a simple, useful and inexpensive means for diagnostic value in several medical disorders for the last several decades.

The Surface of the skin and its deeper structures show over 35 different named linear markings. Papillary ridges (friction ridges) are confined to the palms, soles and the flexor surfaces of the digits. Along the summit of each ridge the apertures of swear ducts open at regular intervals. The arrangement of which is stable through out life and unique to the individual and therefore significant as a means of indemnification and as tool of diagnosis in various genetic and medical disorders.

A fingerprint is an impression of the friction ridges of all or any part of the finger. A friction ridge is a raised portion of the epidermis on the skin of palmar: palm and fingers or plantar: sole and toes, consisting of one or more connected ridge units on skin. These ridges are also known as dermal ridges or dermal papillae. Fingerprints may be deposited in natural secretions from the eccrine glands present in friction ridge skin (secretions consisting primarily of water) or they may be made by ink or other contaminants transferred from the peaks of friction skin ridges to a relatively smooth surface such as a fingerprint card.

Diabetes Mellitus (DM) can be defined today, in the light of new progress in the fields of etiology, pathogenic, diagnosis and therapy as a heterogeneous etiological syndrome, characterized by a profound and complex turbulence of the energetic metabolism. The energetic metabolism is involved through the glucidic metabolism (hyperglycemia and, or glucosurie), the proteinic metabolism (hiperuemia and hiperuria) and the lipidic metabolism. It is associated to then the resistance or incapacity of peripherical tissues of using the insulin necessary to transform glucose into glycogen, as a reserve of energetic substance.

Therefore, we can say that DM is a disease of the whole organism, involving directly or indirectly almost all body cells, tissues and organs and whose gravity depends on the organism's genetic luggage, on the degree and duration of the metabolic imbalance. Consequently, the disease complications may be multiple.

The insulin dependent diabetes or Diabetes Mellitus type 1 (T1DM) named by the great French doctor Lancereaux since 1877, the pancreatic or weak diabetes (at which the pancreatic cells $\beta$ issuing insulin are destroyed in a percentage of $90 \%$, and the non insulin dependent diabetes or insulin independent one Diabetes Mellitus type 2 (T2DM) named by the same Lancereaux and the fat diabetes or constitutional one, present in 85 $-90 \%$ out of total number of suffering of diabetes. The diabetes type 1(T1DM) which makes the object of our study, is significant for the groups of age of up top 30-40, but especially for $1-18$ ages.

T1DM, that begins noisily from the clinical point of view, by obvious symptoms like: asthenia, tiredness, polyuria, polyphagy, polydipsy, weight loss, may be in its turn Primary Insulin dependent (that necessitates insulin therapy from the very beginning and represents approximately $7 \%$ of the total number of patients) and secondary insulin-dependent.

The first proofs of the $\beta$ cellular dysfunctions in T1DM appear when these cells mass is reduced at its half and the disease release as such in signaled when $90 \%$ of the insular tissue is destroys. The present paper was performed in order to study dermatoglyphics pathology in T1DM,

\section{Materials and Methods}

Dermatoglyphic Patterns were studied in eighty cases (48 Females and 32 Males) of diagnosed type - I Diabetes Mellitus and they were compared with Sixty three cases of healthy invidudals who were taken as controls. All are between the age groups of 10 and 20 years.

These patients were taken at random from department of internal medicine SVS medical college and hospital. Eighty Healthy Medical Students of SVS medical college and hospital were selected as control. 
The Materials Used For Taking Prints Were:

Block ink (Thumb impression ink), Glass slab, Roller, Spirit, Magnifying lens, good quality paper.

A small amount of ink is placed on the inking slab and spread with roller into a think even film. The ink was applied gently and evenly to the patient's palms and fingers by keeping it contact on ink film prepared on the ink slab.

The prints of both hands, right and left taken on separate clean papers and labeled properly. The dermatoglyphic analysis was conducted in Type - I Insulin Dependant Diabetes mellitus patients and controls on the following lines.

Types of fingertip patterns:

A - Simple arch

B-Tented arch

E-Simple whorl

F-Central pocket whorl.
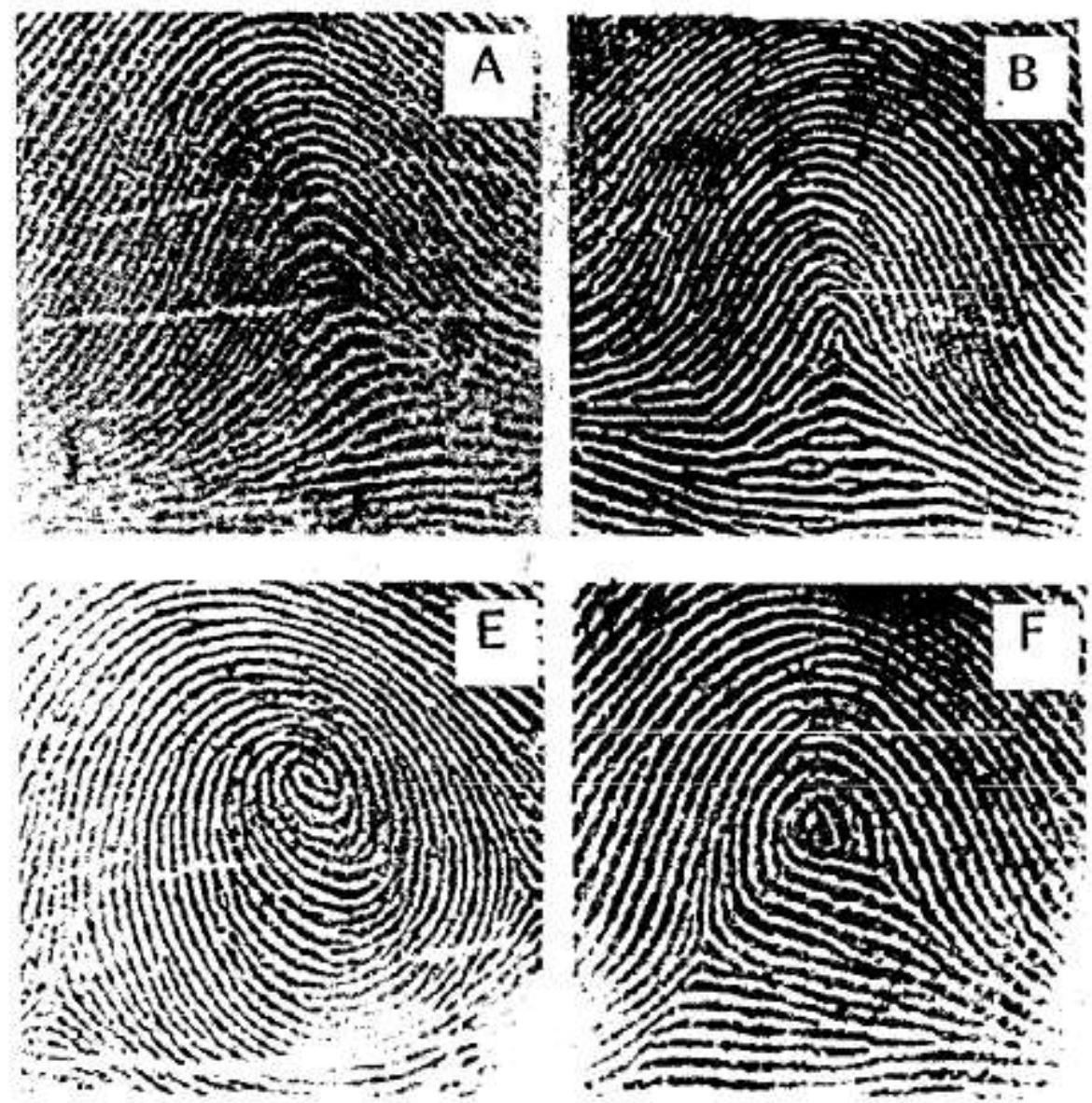

Types of fingertip patterns

C: Ulnar Loop

D: Radial Loop

G: Double Loop Whorl

H: Accidental Whorl 

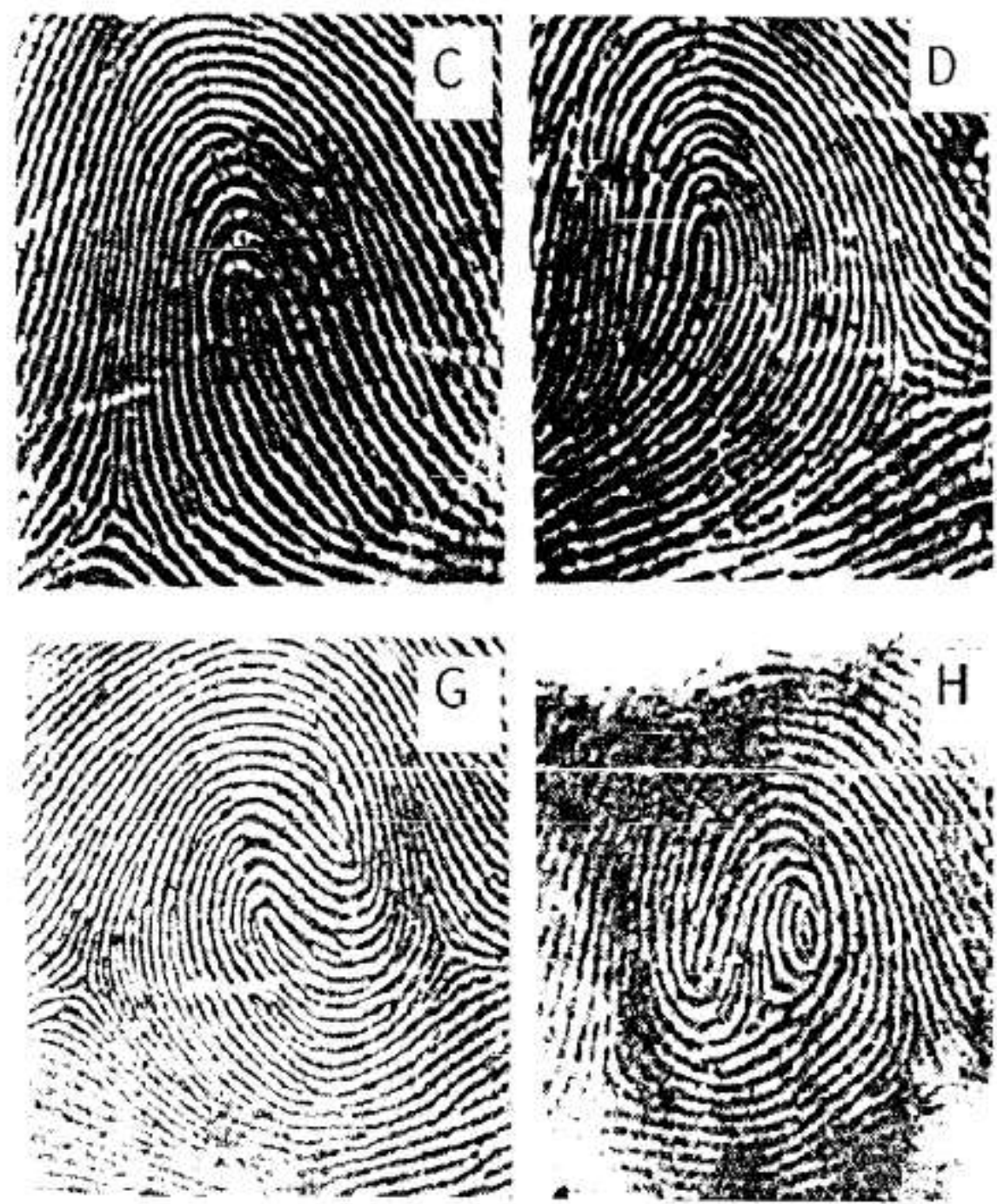

The parameters taken are:

1. The finger print distribution of all ten fingers of both hands of combined groups of juvenile diabetics and control (TFRC).

2. Frequency of digital patterns (arches, loops and whorls).

3. atd angle.

4. adt angle.

5. a-b ridge count.

\section{Observations}

The present study was undertaken on eighty patients of IDDM (Type - I diabetes Mellitus) (forty eight females and thirty tow males patients) and normal patients (forty females and fourty males).

1. Ulnar loops show maximum percentage frequency in both right and left hands of female's patients and controls.

2. TFRC is high in normal females and decreased in patients.

3. $\quad$ a-b ridge count is also decreased in patients when compared to normal controls.

4. Presence of axial triradius is increased in patients when compared to normal controls.

5. Ulnar loops shows increased percentage frequency in first and fifth finger of normal controls whereas whorls shows increased percentage frequency in $1^{\text {st }}$ digit of both right and left hands of patients.

II

1. Ulnar loops show maximum percentage frequency in both right and left hands of male normal controls whereas whorls shows maximum percentage frequency in right and left hands of male patients. TFRC is 
high in controls and decreased in IDDM male patients. a-b ridge count is decreased in IDDM male patients wen compared to controls. Presence of axial triradius is high in patients when compared to controls

2. 2 ulnar loops show increased percentage frequency in $1^{\text {st }}$ and $\mathrm{V}^{\text {th }}$ digit of controls whereas whorls shows increased percentage frequency in $1^{\text {st }}$ and $5^{\text {th }}$ digit of IDDM patients.
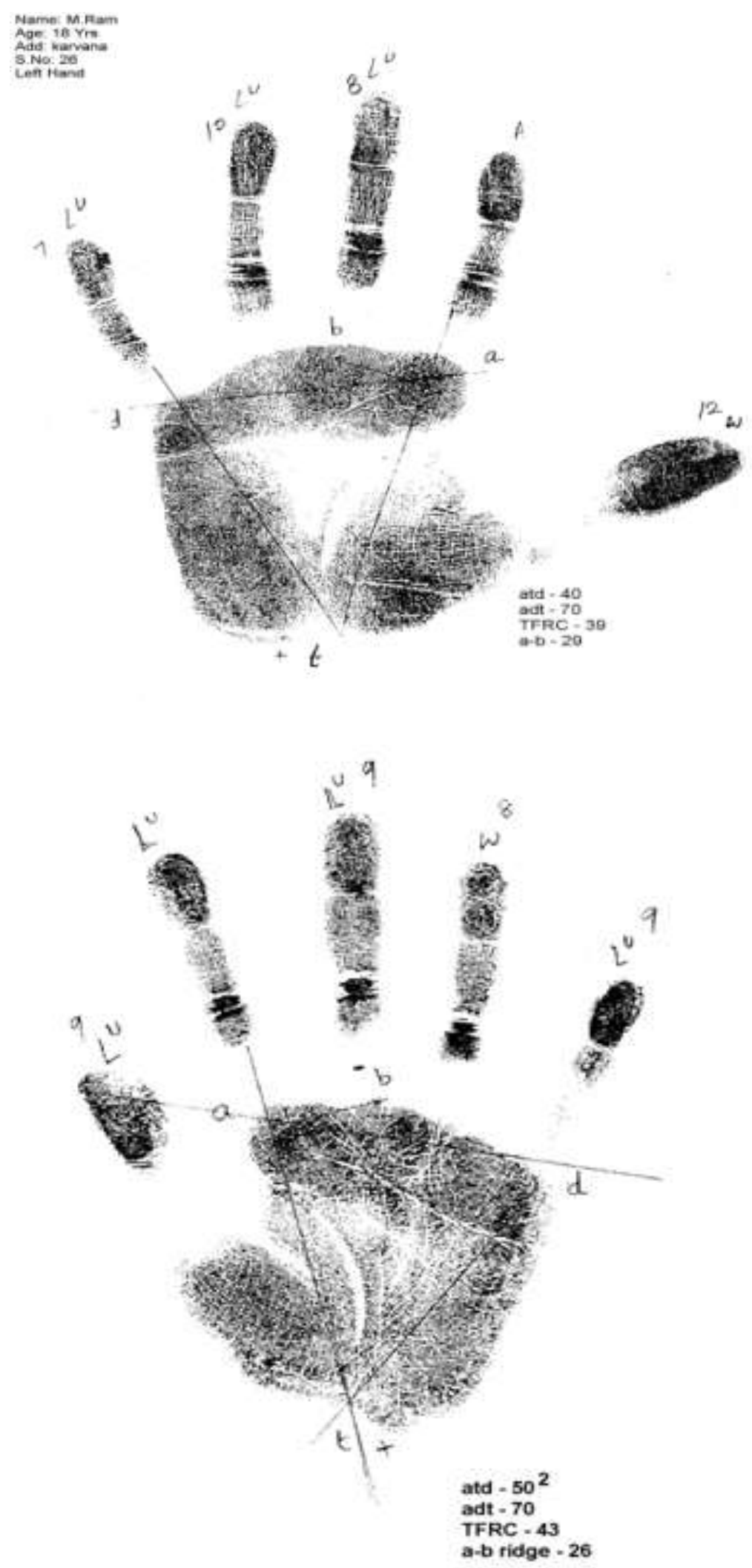


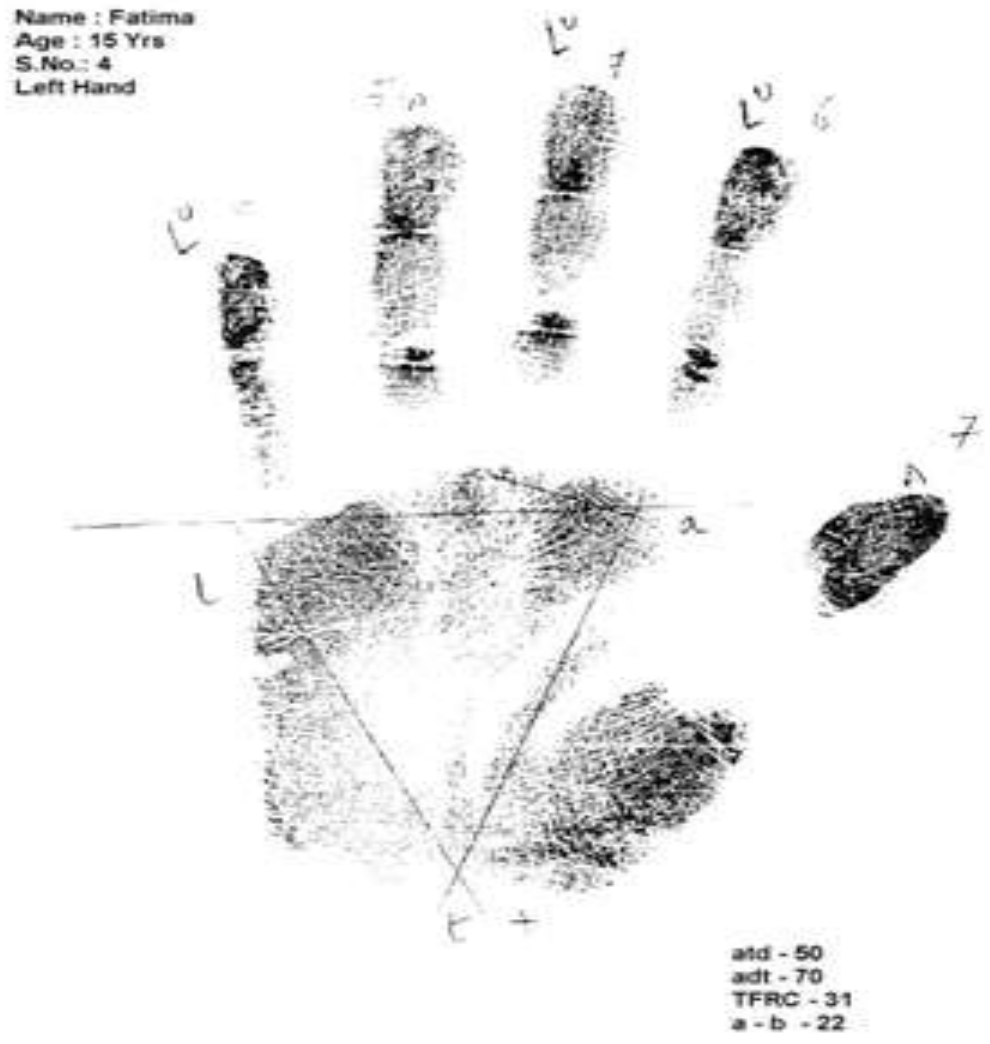

\section{Digital Dermatoglyphics}

The Following salient features are derived from statistical analysis by SPSS-PC package showing the comparative digital pattern distribution between controls and patients of the same sex.

1. In female controls, first digit shows three patterns, arches, ulnar loops and whorls. Out of these, $70.0 \%$ are ulnar loops, arches 5\%. In IDDM female patients three patterns are seen. Out of these, whorls are $70.8 \%$, arches $22.9 \%$, ulnar loops $6.3 \%$.

2. In normal's, second digit shows ulnar loops $45 \%$, arches $17.5 \%$, radial loops $2.5 \%$, and whorls $35 \%$. All four patterns are seen in both controls and patients. In Female patients ulnar loops 43.8\%, whorls $39.6 \%$, arches $8.3 \%$, radial loops $8.3 \%$.

3. TFRC mean in normal's 130.80 and in patients 67.33 , S.D. in controls 17.47 , in patients 6.14 . In controls ab ridge count mean is 77.45, in patients 55.77, S.D. in normal's 10.08 and in patients 7.32 .

4. In male controls first digit shows $43.5 \%$ ulnar loops, $39.1 \%$ whorls, $17.4 \%$ arches. In male IDDM patients whorls $84.4 \%$, ulnar loops $9.4 \%$, arches $6.3 \%$.

5. In male controls second digit shows all four patterns, whorls $47.8 \%$, ulnar loops $26.1 \%$, radial loops $17.4 \%$, arches 8.7. In male IDDM patients, $40.6 \%$ whorls, ulnar loops $28.1 \%$, arches $28.1 \%$, radial loops $3.1 \%$.

6. TFRC means in controls 138.69 and S.D is 16.54 and in IDDM patients, the TFRC mean is 75.62 and S.D is 7.20. In controls, the mean of a-b ridge count is 85.91, S.D. is 8.67. In IDDM patients, means is 56.18 and S.D is 4.00. Both TFRC and a-b ridge counts are decreased in IDDM patients.

7. The individual analysis of digital prints for patients with T1DM, showed important anomalies or distortions with deep clinical implications, both in the case of those for which the release of the disease occurred in childhood or adolescence and with a later release of the disease.

Table - I The Percentage frequency of digits in controls and patients

\begin{tabular}{|l|l|l|l|l|l|}
\hline $\begin{array}{l}\text { Male } \\
\text { Right Hand }\end{array}$ & Arches & L, U & R, L & Whorls & Total \\
\hline 1st Digit Control & 4 & 10 & 0 & 9 & 23 \\
& $17.4 \%$ & $43.5 \%$ & 0 & 39.1 & $100.0 \%$ \\
\hline Patient & 2 & 3 & 0 & 27 & 32 \\
& $6.3 \%$ & $9.4 \%$ & 0 & $84.4 \%$ & $100.0 \%$ \\
\hline
\end{tabular}


A Study Of Dermatoglyphics In Insulin Dependent Diabetes Mellitus

\begin{tabular}{|c|c|c|c|c|c|}
\hline $2^{\text {nd }}$ Digit Control & $\begin{array}{l}2 \\
8.7 \%\end{array}$ & $\begin{array}{l}6 \\
26.1 \%\end{array}$ & $\begin{array}{l}4 \\
17.4 \%\end{array}$ & $\begin{array}{l}11 \\
47.8 \%\end{array}$ & $\begin{array}{l}23 \\
100.0 \%\end{array}$ \\
\hline Patient & $\begin{array}{l}9 \\
28.1 \%\end{array}$ & $\begin{array}{l}9 \\
28.1 \%\end{array}$ & $\begin{array}{l}1 \\
3.01 \%\end{array}$ & $\begin{array}{l}13 \\
40.6 \%\end{array}$ & $\begin{array}{l}32 \\
100.0 \%\end{array}$ \\
\hline $3^{\text {rd }}$ Digit Control & $\begin{array}{l}0 \\
0\end{array}$ & $\begin{array}{l}14 \\
16.9 \%\end{array}$ & $\begin{array}{l}0 \\
0\end{array}$ & $\begin{array}{l}9 \\
39.1 \% \\
\end{array}$ & $\begin{array}{l}23 \\
100.0 \% \\
\end{array}$ \\
\hline Patient & $\begin{array}{l}4 \\
12.5 \%\end{array}$ & $\begin{array}{l}18 \\
56.3 \%\end{array}$ & $\begin{array}{l}0 \\
0\end{array}$ & $\begin{array}{l}10 \\
31.1 \%\end{array}$ & $\begin{array}{l}32 \\
100.0 \%\end{array}$ \\
\hline $\begin{array}{l}4^{\text {th }} \text { Digit } \\
\text { Control }\end{array}$ & $\begin{array}{l}1 \\
4.3 \%\end{array}$ & $\begin{array}{l}6 \\
26.1 \%\end{array}$ & $\begin{array}{l}1 \\
4.3 \%\end{array}$ & $\begin{array}{l}15 \\
65.2 \%\end{array}$ & $\begin{array}{l}23 \\
100.0 \%\end{array}$ \\
\hline Patient & $\begin{array}{l}1 \\
3.1 \% \\
\end{array}$ & $\begin{array}{l}15 \\
46.9 \%\end{array}$ & $\begin{array}{l}1 \\
3.1 \% \\
\end{array}$ & $\begin{array}{l}15 \\
46.9 \%\end{array}$ & $\begin{array}{l}32 \\
100.0 \%\end{array}$ \\
\hline $\begin{array}{l}5^{\text {th }} \text { Digit } \\
\text { Control }\end{array}$ & $\begin{array}{l}1 \\
4.3 \% \\
\end{array}$ & $\begin{array}{l}16 \\
69.6 \%\end{array}$ & $\begin{array}{l}0 \\
0\end{array}$ & $\begin{array}{l}6 \\
26.1 \%\end{array}$ & $\begin{array}{l}23 \\
100.0 \%\end{array}$ \\
\hline Patient & $\begin{array}{l}3 \\
9.4 \% \\
\end{array}$ & $\begin{array}{l}23 \\
71.9 \% \\
\end{array}$ & $\begin{array}{l}0 \\
0\end{array}$ & $\begin{array}{l}6 \\
18.8 \% \\
\end{array}$ & $\begin{array}{l}32 \\
100.0 \% \\
\end{array}$ \\
\hline $\begin{array}{l}\text { Male } \\
\text { Left Hand }\end{array}$ & Arches & $\mathbf{L}, \mathbf{U}$ & $\mathbf{R}, \mathbf{L}$ & Whorls & Total \\
\hline $\begin{array}{l}\text { 1st Digit } \\
\text { Control }\end{array}$ & $\begin{array}{l}5 \\
21.7 \%\end{array}$ & $\begin{array}{l}10 \\
43.5 \%\end{array}$ & $\begin{array}{l}0 \\
0\end{array}$ & $\begin{array}{l}8 \\
34.8 \%\end{array}$ & $\begin{array}{l}23 \\
100.0 \%\end{array}$ \\
\hline Patient & $\begin{array}{l}0 \\
0\end{array}$ & $\begin{array}{l}5 \\
16.6 \%\end{array}$ & $\begin{array}{l}0 \\
0\end{array}$ & $\begin{array}{l}27 \\
84.4 \%\end{array}$ & $\begin{array}{l}32 \\
100.0 \%\end{array}$ \\
\hline $\begin{array}{l}2^{\text {nd }} \text { Digit } \\
\text { Control }\end{array}$ & $\begin{array}{l}2 \\
8.7 \%\end{array}$ & $\begin{array}{l}8 \\
38.8 \%\end{array}$ & $\begin{array}{l}2 \\
8.7 \%\end{array}$ & $\begin{array}{l}11 \\
47.8 \%\end{array}$ & $\begin{array}{l}23 \\
100.0 \%\end{array}$ \\
\hline Patient & $\begin{array}{l}9 \\
28.1 \%\end{array}$ & $\begin{array}{l}8 \\
25.0 \%\end{array}$ & $\begin{array}{l}0 \\
0\end{array}$ & $\begin{array}{l}15 \\
46.9 \%\end{array}$ & $\begin{array}{l}32 \\
100.0 \%\end{array}$ \\
\hline $\begin{array}{l}3^{\text {rd }} \text { Digit } \\
\text { Control }\end{array}$ & $\begin{array}{l}1 \\
4.3 \%\end{array}$ & $\begin{array}{l}17 \\
73.9 \%\end{array}$ & $\begin{array}{l}0 \\
0\end{array}$ & $\begin{array}{l}5 \\
21.7 \%\end{array}$ & $\begin{array}{l}23 \\
100.0 \%\end{array}$ \\
\hline Patient & $\begin{array}{l}4 \\
12.5 \%\end{array}$ & $\begin{array}{l}17 \\
53.1 \%\end{array}$ & $\begin{array}{l}0 \\
0\end{array}$ & $\begin{array}{l}11 \\
34.4 \%\end{array}$ & $\begin{array}{l}32 \\
100.0 \%\end{array}$ \\
\hline $\begin{array}{l}4^{\text {th }} \text { Digit } \\
\text { Control }\end{array}$ & $\begin{array}{l}0 \\
0\end{array}$ & $\begin{array}{l}12 \\
52.2 \%\end{array}$ & $\begin{array}{l}0 \\
0\end{array}$ & $\begin{array}{l}11 \\
47.8 \%\end{array}$ & $\begin{array}{l}23 \\
100.0 \%\end{array}$ \\
\hline Patient & $\begin{array}{l}1 \\
3.1 \%\end{array}$ & $\begin{array}{l}16 \\
50.0 \%\end{array}$ & $\begin{array}{l}0 \\
0\end{array}$ & $\begin{array}{l}15 \\
46.9 \%\end{array}$ & $\begin{array}{l}32 \\
100.0 \%\end{array}$ \\
\hline $\begin{array}{l}5^{\text {th }} \text { Digit } \\
\text { Control }\end{array}$ & $\begin{array}{l}1 \\
4.3 \%\end{array}$ & $\begin{array}{l}20 \\
87.0 \%\end{array}$ & $\begin{array}{l}0 \\
0\end{array}$ & $\begin{array}{l}2 \\
8.7 \%\end{array}$ & $\begin{array}{l}23 \\
100.0 \%\end{array}$ \\
\hline Patient & $\begin{array}{l}3 \\
9.4 \%\end{array}$ & $\begin{array}{l}20 \\
62.5 \%\end{array}$ & $\begin{array}{l}0 \\
0\end{array}$ & $\begin{array}{l}9 \\
28.1 \%\end{array}$ & $\begin{array}{l}32 \\
100.0 \%\end{array}$ \\
\hline
\end{tabular}

Table - II The Percentage frequency of digits in controls and patients

\begin{tabular}{|c|c|c|c|c|c|}
\hline $\begin{array}{l}\text { Female } \\
\text { Right Hand }\end{array}$ & Arches & $\mathbf{L}, \mathbf{U}$ & $\mathbf{R}, \mathbf{L}$ & Whorls & Total \\
\hline 1st Digit Control & $\begin{array}{l}2 \\
5.0 \%\end{array}$ & $\begin{array}{l}28 \\
70.0 \%\end{array}$ & $\begin{array}{l}0 \\
0\end{array}$ & $\begin{array}{l}10 \\
25.0 \%\end{array}$ & $\begin{array}{l}40 \\
100.0 \%\end{array}$ \\
\hline Patient & $\begin{array}{l}11 \\
22.9 \%\end{array}$ & $\begin{array}{l}3 \\
6.3 \%\end{array}$ & $\begin{array}{l}0 \\
0\end{array}$ & $\begin{array}{l}34 \\
70.8 \%\end{array}$ & $\begin{array}{l}48 \\
100.0 \%\end{array}$ \\
\hline $2^{\text {nd }}$ Digit Control & $\begin{array}{l}7 \\
17.5 \%\end{array}$ & $\begin{array}{l}18 \\
45.0 \%\end{array}$ & $\begin{array}{l}1 \\
2.5 \%\end{array}$ & $\begin{array}{l}14 \\
35.0 \%\end{array}$ & $\begin{array}{l}40 \\
100.0 \%\end{array}$ \\
\hline Patient & $\begin{array}{l}4 \\
8.3 \%\end{array}$ & $\begin{array}{l}21 \\
43.8 \%\end{array}$ & $\begin{array}{l}4 \\
8.3 \%\end{array}$ & $\begin{array}{l}19 \\
39.6 \%\end{array}$ & $\begin{array}{l}48 \\
100.0 \%\end{array}$ \\
\hline $3^{\text {rd }}$ Digit Control & $\begin{array}{l}0 \\
0\end{array}$ & $\begin{array}{l}30 \\
75.0 \%\end{array}$ & $\begin{array}{l}0 \\
0\end{array}$ & $\begin{array}{l}10 \\
25.0 \%\end{array}$ & $\begin{array}{l}40 \\
100.0 \%\end{array}$ \\
\hline Patient & $\begin{array}{l}0 \\
0\end{array}$ & $\begin{array}{l}42 \\
87.5 \%\end{array}$ & $\begin{array}{l}0 \\
0\end{array}$ & $\begin{array}{l}6 \\
12.5 \%\end{array}$ & $\begin{array}{l}48 \\
100.0 \%\end{array}$ \\
\hline $\begin{array}{l}4^{\text {th }} \text { Digit } \\
\text { Control }\end{array}$ & $\begin{array}{l}1 \\
2.5 \%\end{array}$ & $\begin{array}{l}19 \\
47.5 \%\end{array}$ & $\begin{array}{l}0 \\
0\end{array}$ & $\begin{array}{l}20 \\
50.0 \%\end{array}$ & $\begin{array}{l}40 \\
100.0 \%\end{array}$ \\
\hline Patient & $\begin{array}{l}0 \\
0\end{array}$ & $\begin{array}{l}26 \\
54.2 \%\end{array}$ & $\begin{array}{l}0 \\
0\end{array}$ & $\begin{array}{l}22 \\
45.8 \%\end{array}$ & $\begin{array}{l}48 \\
100.0 \%\end{array}$ \\
\hline $\begin{array}{l}5^{\text {th }} \text { Digit } \\
\text { Control }\end{array}$ & $\begin{array}{l}5 \\
12.5 \%\end{array}$ & $\begin{array}{l}28 \\
70.0 \%\end{array}$ & $\begin{array}{l}0 \\
0\end{array}$ & $\begin{array}{l}7 \\
17.5 \%\end{array}$ & $\begin{array}{l}40 \\
100.0 \%\end{array}$ \\
\hline Patient & $\begin{array}{l}6 \\
12.5 \%\end{array}$ & $\begin{array}{l}32 \\
66.7 \%\end{array}$ & $\begin{array}{l}0 \\
0\end{array}$ & $\begin{array}{l}10 \\
20.8 \%\end{array}$ & $\begin{array}{l}48 \\
100.0 \%\end{array}$ \\
\hline $\begin{array}{l}\text { Female } \\
\text { Left Hand }\end{array}$ & Arches & $\mathbf{L}, \mathbf{U}$ & $\mathbf{R}, \mathbf{L}$ & Whorls & Total \\
\hline
\end{tabular}


A Study Of Dermatoglyphics In Insulin Dependent Diabetes Mellitus

\begin{tabular}{|l|l|l|l|l|l|}
\hline 1st Digit & 2 & 28 & 0 & 10 & 40 \\
Control & $5.0 \%$ & $70.0 \%$ & 0 & $25.0 \%$ & $100.0 \%$ \\
\hline Patient & 15 & 3 & 0 & 30 & 48 \\
& $31.3 \%$ & $6.3 \%$ & 0 & $62.5 \%$ & $100.0 \%$ \\
\hline $2^{\text {nd }}$ Digit & 7 & 18 & 1 & 14 & 40 \\
Control $^{17.5 \%}$ & $45.0 \%$ & $2.5 \%$ & $35.0 \%$ & $100.0 \%$ \\
\hline Patient & 9 & 15 & $2.7 \%$ & & \\
& $8.8 \%$ & $31.3 \%$ & $4.2 \%$ & $45.8 \%$ & 48 \\
\hline $3^{\text {rd }}$ Digit & 0 & 30 & 0 & $100.0 \%$ \\
\hline Control & 0 & $75.0 \%$ & 0 & $25.0 \%$ & 40 \\
\hline Patient & 2 & 38 & 0 & 8 & $400.0 \%$ \\
& $4.2 \%$ & $79.2 \%$ & 0 & $16.7 \%$ & $100.0 \%$ \\
\hline $4^{\text {th }}$ Digit & 1 & 19 & 0 & 20 & 40 \\
Control & $2.5 \%$ & $47.5 \%$ & 0 & $50.0 \%$ & $100.0 \%$ \\
\hline Patient & 0 & 25 & 1 & 22 & 48 \\
& 0 & $52.1 \%$ & $2.1 \%$ & $45.8 \%$ & $100.0 \%$ \\
\hline $5^{\text {th }}$ Digit & 5 & 28 & 0 & 7 & 40 \\
Control & $12.5 \%$ & $70.0 \%$ & 0 & $17.5 \%$ & $100.0 \%$ \\
\hline Patient & 3 & 35 & 0 & 10 & 48 \\
& $6.3 \%$ & $72.9 \%$ & 0 & $20.8 \%$ & $100.0 \%$ \\
\hline
\end{tabular}

TFRC and a-b ridge counts mean values of male and female controls and patients

\begin{tabular}{|l|l|l|l|l|}
\hline Male & Status & N & Mean & Std. Deviation \\
\hline \multirow{2}{*}{ TFRC } & Control & 23 & 138.69 & 16.54 \\
& Patient & 32 & 75.62 & 7.20 \\
\hline \multirow{2}{*}{ a-b Ridge Count } & Control & 23 & 85.91 & 8.67 \\
& Patient & 32 & 56.18 & 4.00 \\
\hline Female & Status & $\mathbf{N}$ & Mean & Std. Deviation \\
\hline \multirow{2}{*}{ TFRC } & Control & 40 & 130.80 & 17.47 \\
& Patient & 42 & 67.33 & 6.14 \\
\hline \multirow{2}{*}{ a-b Ridge Count } & Control & 40 & 77.45 & 10.08 \\
& Patient & 42 & 55.77 & 7.32 \\
\hline
\end{tabular}

Table - IV: atd and adt angles mean values of Male and Female control patients.

\begin{tabular}{|l|l|l|l|l|}
\hline Male & Status & N & Mean & Std. Deviation \\
\hline \multirow{2}{*}{ Right atd } & Control & 23 & 39.52 & 8.816 \\
& Patient & 32 & 38.44 & 2.961 \\
\hline \multirow{2}{*}{ Right adt } & Control & 23 & 76.30 & 5.756 \\
& Patient & 32 & 74.38 & 3.9666 \\
\hline \multirow{3}{*}{ Left adt } & Control & 23 & 40.00 & 3.015 \\
& Patient & 32 & 39.69 & 2.520 \\
\hline \multirow{2}{*}{ Female } & Control & 23 & 75.70 & 5.497 \\
\hline \multirow{2}{*}{ Right atd } & Patient & 32 & 75.00 & 4.752 \\
\hline \multirow{2}{*}{ Right adt } & Status & N & Mean & Std. Deviation \\
\hline \multirow{2}{*}{ Left atd } & Control & 40 & 38.25 & 3.499 \\
\hline \multirow{2}{*}{ Left adt } & Patient & 48 & 44.85 & 4.327 \\
\hline
\end{tabular}

\section{Mean value of TFRC and a-b Ridge count - Table III}

\section{Summary and Conclusion}

- The Study of dermatoglyphics was done on eighty IDDM patients both male and female and compared with eighty normal controls. 
- Whorls are chiefly confined to digit I of both female and male IDDM patients.

- Ulnar loops shows dominance in all digits except in digit-I in male IDDM patients.

- Radial loops were present only in digit-II of both male and female IDDM patients.

- The number of axial triradius both in female and male IDDM patients which is increased when compared to controls.

- The mean atd and adt angles show approximately similar readings in both sexes.

- TFRC and a-b ridge count are decreased both in male and female patients.

- Arches were present in I, II and V Digits in both female and make IDDM patients.

Dermatoglyphic formation involves both genetic and environment contributions. It seems likely that disordered early fetal development accounts partly for the aetiology of IDDM and the dermatoglyphic should be demonstrable in those patients.

\section{Reference}

[1]. Dermatoglyphic study in type I diabetes mellitus saksena p.n. and thakur S. 1979

[2]. Evaluation of dermatoglyphics in juvenile diabetes Vera.M.,Cabrera E.,Guell R. 1995

[3]. Dermatoglyphic features in diabetes mellitus, Act paeditric Acad Soi Hung, L.V.Dzhanibekova , L.V. Lebeder N.B., Kurarva T.L 1994.

[4]. A.L.regoly merie,A,Kammererl 1978

[5]. European Association for Study of Diabetes (EASD). General Information of the EASD. http:/www.easd.org/customfiles/geninfo.htm.20042004

[6]. World Health Organization 2004 (WHO) and International Diabetes Federation (IDF), 2004: Diabetes action now-an initiative of the WHO and IDF. www.who.int/diabetes and www.idf.org. 